\title{
TRENDS IN DEVELOPMENT OF RESIDENTIAL AREAS IN SUBURBAN ZONE OF THE CITY OF NITRA (SLOVAKIA)
}

Gabriela Repaská, Katarína Vilinová, Lucia Šolcová1

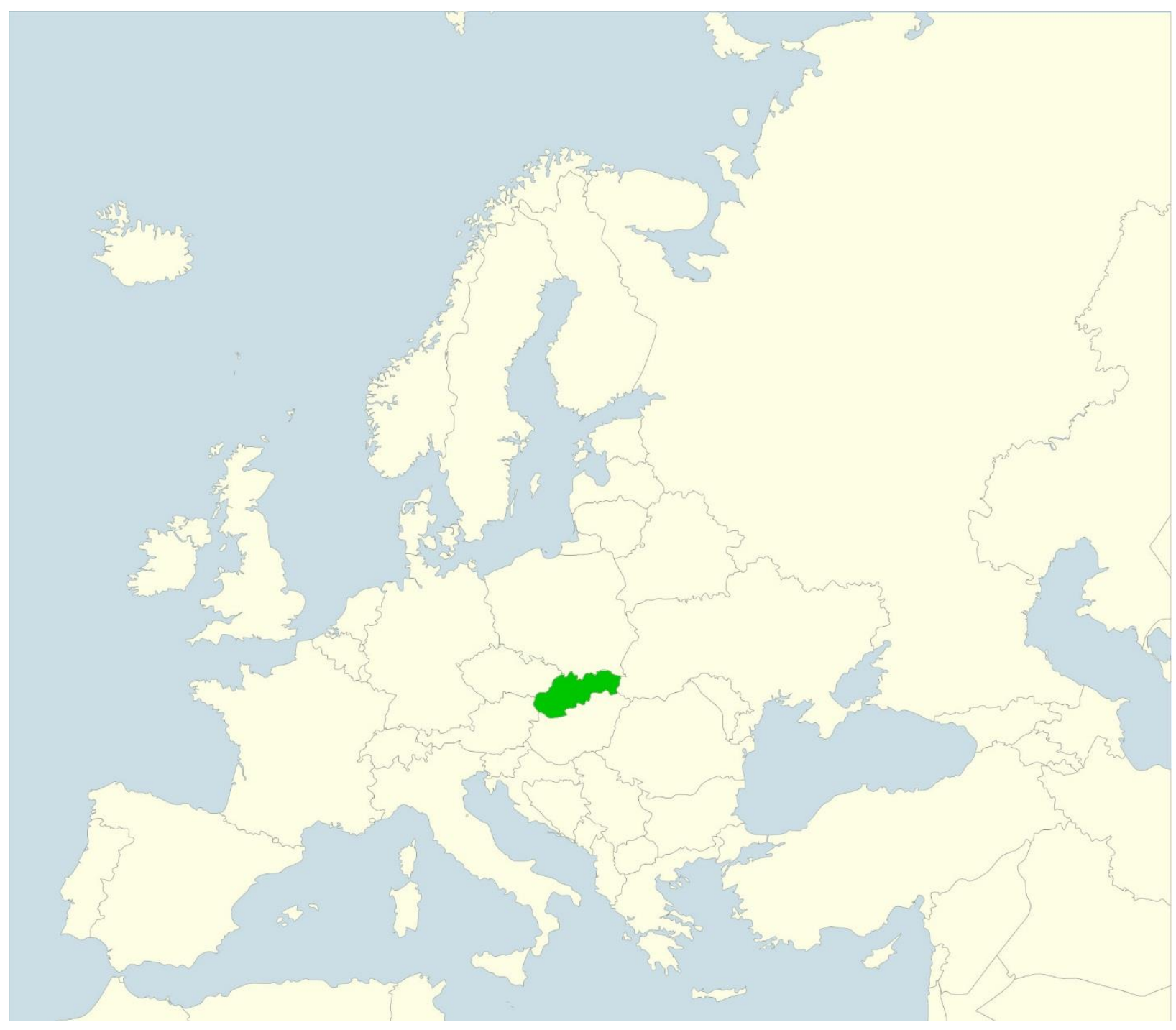

1 RNDr. Gabriela Repaská, PhD., RNDr. Katarína Vilinová, PhD., RNDr. Lucia Šolcová, PhD., Department of Geography and Regional Development, Faculty of Natural Sciences, Constantine the Philosopher University in Nitra. Address: Trieda A. Hlinku 1, 94974 Nitra, Slovakia; E-mails: grepaska@ukf.sk, kvilinova@ukf.sk, Isolcova@ukf.sk 
Abstract: Political changes in Slovakia after 1989 initiated new economic trends which significantly affected the structure of cities and rural municipalities. The process of suburbanization has changed the rural landscape with a widespread increase in new residential areas. Based on an analysis of residential suburbanization, the aim of the paper is to describe the encroachment of residential construction in the suburban zone of Nitra through increase in the size of the housing stock, number of housing types and the spatial localization of suburban construction. Such analysis of residential development contributes to the knowledge of the extent and intensity of the residential suburbanization process in the outskirts of the city of Nitra. Theoretical analysis of residential suburbanization is based on the relevant literature, placing it into context alongside the works of authors from Western and Central Europe. The research is based on standard geographical methods including field research. To compare the changes in residential areas aerial photos from 2001 and 2015 were used. Results show that in the municipalities of the suburban zone significant changes have occurred in the building sprawl, thus changing the face of rural municipalities and the character of the rural landscape.

Key words: settlement building, suburban zone, suburbanization, family homes

Abstrakt: Politické zmeny na Slovensku po roku 1989 iniciovali nové ekonomické záujmy, ktoré výrazne ovplyvnili štruktúru miest a vidieckych obcí. Práve proces suburbanizácie zmenil vidiecku krajinu rozsiahlym nárastom nových obytných častí sídiel. Ciel'om príspevku je na základe analýzy rezidenčnej suburbanizácie vyjadrit' rozrastanie rezidenčnej výstavby $v$ suburbánnej zóne mesta Nitra prostredníctvom vývoja počtu domového fondu, foriem bývania a priestorovej lokalizácie suburbánnej výstavby. Takto hodnotená rezidenčná výstavba prispieva k poznaniu rozsahu a intenzity procesov rezidenčnej suburbanizácie $v$ zázemí mesta Nitra. Teoretická charakteristika rezidenčnej suburbanizácie vychádza z relevantnej literatúry ktorá ju dáva do kontextu s názormi autorov zo západnej a strednej Európy. K naplneniu ciel'a vychádzame zo štatistických metód, metódy terénneho výskumu, ako aj z leteckých snímkov, ktoré sú nenahraditel'ným pomocníkom pri priestorovej vizualizácii rezidenčnej výstavby. Pre porovnanie zmien sídelnej zástavby boli použité letecké snímky z rokov 2001 a 2015. Výsledky poukazujú na to, že v sídlach suburbánnej zóny nastali v rozrastaní zástavby výrazné zmeny, čím sa zmenila tvár vidieckych sídiel a samotný krajinný ráz celého vidieka.

Kl'účové slová: rezidenčná suburbanizácia, suburbánna zóna, suburbánne domy, Nitra, Slovensko

\section{Introduction}

Housing is one of the issues most addressed by the population, as it is a fundamental aspect of their lives. It indicates the social development of a society, living standards of a population and the quality of life related to it. It represents one of the basic needs of every individual - shelter. It is part of social development, based on the integration of the individual into society. Single-family homes and apartments are an essential feature of settlements; they are one of the most important concepts of the functional and spatial structure of cities and rural villages. They indicate social classes within a society in the context of housing quality. Currently expansion of construction is taking place in the Slovak countryside. This construction often brings about very inadequate housing types, disregarding an urban layout. The newly built houses are often surrounded by fences that resemble fortified walls, which lead to isolation of the population. Building development is concentrated in locations further away from the city. New projects have been prepared for the construction of small houses. Mortgage subsidies and cheaper land in rural areas have become incentives for city dwellers to buy their own houses with a garden. There has been 
a migration of the population to the countryside, which is seen as ideal in terms of connections to employment sites compared to living in the outskirts of the city.

The aim of the paper is to map trends in the suburban development of residential construction in the suburban zone of the city of Nitra. The assessment includes 14 municipalities of the suburban zone of the city of Nitra which was defined in 2015. Monitoring of residential construction in the studied area is based on:

- Analyses of the development of the size of the housing stock, which was assessed during the years 2001-2015, as the suburbanization of Nitra began to become apparent after 2000.

- Types of housing which were monitored by mapping construction in the field and monitoring the most common types of new housing in the suburban municipalities of the city of Nitra.

- Spatial localization of the suburban construction which is based on the comparison of aerial photographs from 2001 and 2015. Based on the spatial localization, we tried to find out if residential construction is built on existing construction or has created whole complexes of newly built family homes.

Such assessment of residential construction contributes to the knowledge of the extent and intensity of residential suburbanization processes in the surroundings of the city of Nitra. A theoretical analysis of residential suburbanization is based on the relevant literature and is put into context alongside opinions of authors from Western and Central Europe. To fulfil our aims, we used statistical methods and field research as well as aerial photographs which are an indispensable aid in spatial visualization of residential construction.

\section{Theoretical background of paper}

Nowadays the identities of large post-socialist cities are undergoing significant changes. There is an influence of various economic and cultural processes that affect individual localities. Big cities and their processes can be seen in post-socialist Europe as places of first entry of new economic and cultural elements into regions (Borén, Gentile, 2007, Leetmaa et al., 2012, Ouředníček, Špačková, 2013), as a connection between Western and Eastern Europe (Musil, 2005) and as outposts for spreading new development tendencies and trends into other areas. In the large cities alone we can notice key progressive processes through social and settlement geography. After the fall of the Iron Curtain, significant changes have been taking place in the development of settlements, mainly due to the changing migration preferences of the population of postsocialist countries. This has been reflected in the differentiated population development of urban and suburban locations in all post-socialist countries. The growth of the boundaries of large cities at the expense of their core has played a dominant role, in which there are significant morphological and social changes.

Research on suburbanization and its impact was significant in the Anglosphere literature of the 1950s and 1960s (Kramer, 1972). Specific work on suburbanization can be divided into two groups according to the authors' relationship to this process. In the early years of the massive construction of American suburbs, criticism of the anti-suburban approach prevailed. Monotonous architecture, dependence on cars and lack of social cohesion was criticized by the inhabitants of suburbs (Mumford, 1961). Some works emerged later and testified to a variety of housing types and suburban heterogeneity (Kramer, 1972). Both perceptions of suburbs may be seen also today. Today's research on suburbanization can be divided into studies on the evaluation of the spatial aspects of settlement structure on the margins of large cities and studies dedicated to suburban locations related to core cities. Furthermore, geographic studies have assessed the morphology of suburban localities, transport connections, quality of life and many other issues (Kährik, Tammaru, 2008, Timár, Váradi, 2001). According to Ouředníček (2005) current suburbanization research varies according to the perspective of the individual. A negative view is first of all held by authors who deal with suburbanization and its negative impacts on the environment, such as loss of agricultural land, increase in car numbers, and the loss of the original architecture (Putnam, 2000). In contrast, a positive view on the issue is held by authors who analyse the micro-regional level of suburbanization, mainly via fieldwork (Lupi, Musterd, 2006). While in Western Europe and North America suburbanization processes have 
been ongoing since the 1950s, in post-socialist cities these processes had significantly slowed during socialism until they stopped. Until the early 1990s they were limited by several barriers (a non-existent market in land, a lack of private capital, command-driven development etc.), which ruled out the development of suburban housing (Musil, 2005, Tammaru, 2001).

Suburbanization in post-socialist countries is influenced by specific historical, legal and political conditions (Nuissl \& Rink, 2005), which does not allow a straightforward comparison with analogous expressions of the suburbanization process in Western Europe. It should be stressed that in Western Europe suburbanization took place in an environment of strong population and economic growth, while in post-socialist countries, there has been population stagnation and economic transformation. As noted by Nuissl \& Rink (2005) in post-socialist cities there are also multiple processes, such as housing privatization, functional transformation, de-industrialization, and so on. While studying the relevant literature on suburbanization from various post-socialist countries, it is clear that there is no single view on suburbanization or stable definition. Different opinions are mainly associated with a different intensity and spatial expression which influence this process in different geographic, cultural and economic conditions. They reflect the specific conditions of urban development in the post-socialist countries and also seek to link existing processes with the urban "big" concepts of foreign literature (theory of developmental stages of cities, the differential urbanization theory, postmodern concept of urbanization, etc.). The relationship between the core city and its outskirts are characterized by Mayer (2000), who understands how to carry suburbanization of urban functions and activities of the population of the core city into adjacent marginal agglomeration areas. According to Ryšavý and Velíšková (1984, in Ouředníček, 2005) the suburbanization stage of the urbanization process is the stagnating or dwindling of population of core cities, while the greatest increase in population occurs in villages concentrated in suburban areas. The problem of defining the borders of suburban areas is dealt with by many geographers. For example, Cílek and Baše (2005) state that suburbanization is "growth through loose building low-density suburbs outside city places, causing the outflow of the wealthier and more active citizens from the city center." Ouředníček (2005) sees the process of suburbanization as part of the urban development process, i.e. the process of urbanization. Most often it leads to identification of the concept of construction of a residential area in suburban areas of large cities. According to the author, suburbanization carries quantitative characteristics in addition to a qualitative transformation of the physical and social environment of suburban areas. Not only can population growth be studied in this process but also change to the social structure of the population. Tammaru (2001) refers to the loss of boundaries between urban and rural areas by extending building with low density. We agree with the American author Glenn (1973), who defines the suburban zone according to the administrative city limits. Such definition of the suburban area is also accessible from a statistical viewpoint, as individual migration statistics are available for a town as a whole (Statistical Office of the Slovak Republic), but statistical data on migration to specific districts and to rural areas is not available. According to the author, residential suburbanization is simply the movement of population and residential functions from within the administrative borders of the city to a rural area.

\section{Methodological background of paper}

Given that the issue of residential suburbanization and related residential construction combines space-historical, socio-psychological, geographical, economic and environmental aspects, it comes under the research interests of sociological, geographical, economic and environmental disciplines. The evaluation methodology of residential suburbanization in the literature is studied in different ways by Slovak and foreign authors. Some of the publications are based on a theoretical analysis of the issues and study the impact of suburbanization that has affected Western Europe. This includes publications from the authors Soós, Ignitz (2003), Sýkora (2003) and Weclawowicz (1998). The approach of other publications relies on statistical data when studying residential suburbanization - mainly statistical data on migration flows of population (Ott, 2001, Ouředníček, 2007, Sjöberg, Tammaru, 1999, Tammaru et al., 2009, Zębik, 2011). Similarly, the Slovak authors base their evaluation of residential suburbanization on migration analysis (Matlovič, Sedláková, 2007, Repaská et al., 2015, Slavík et al., 2011). 

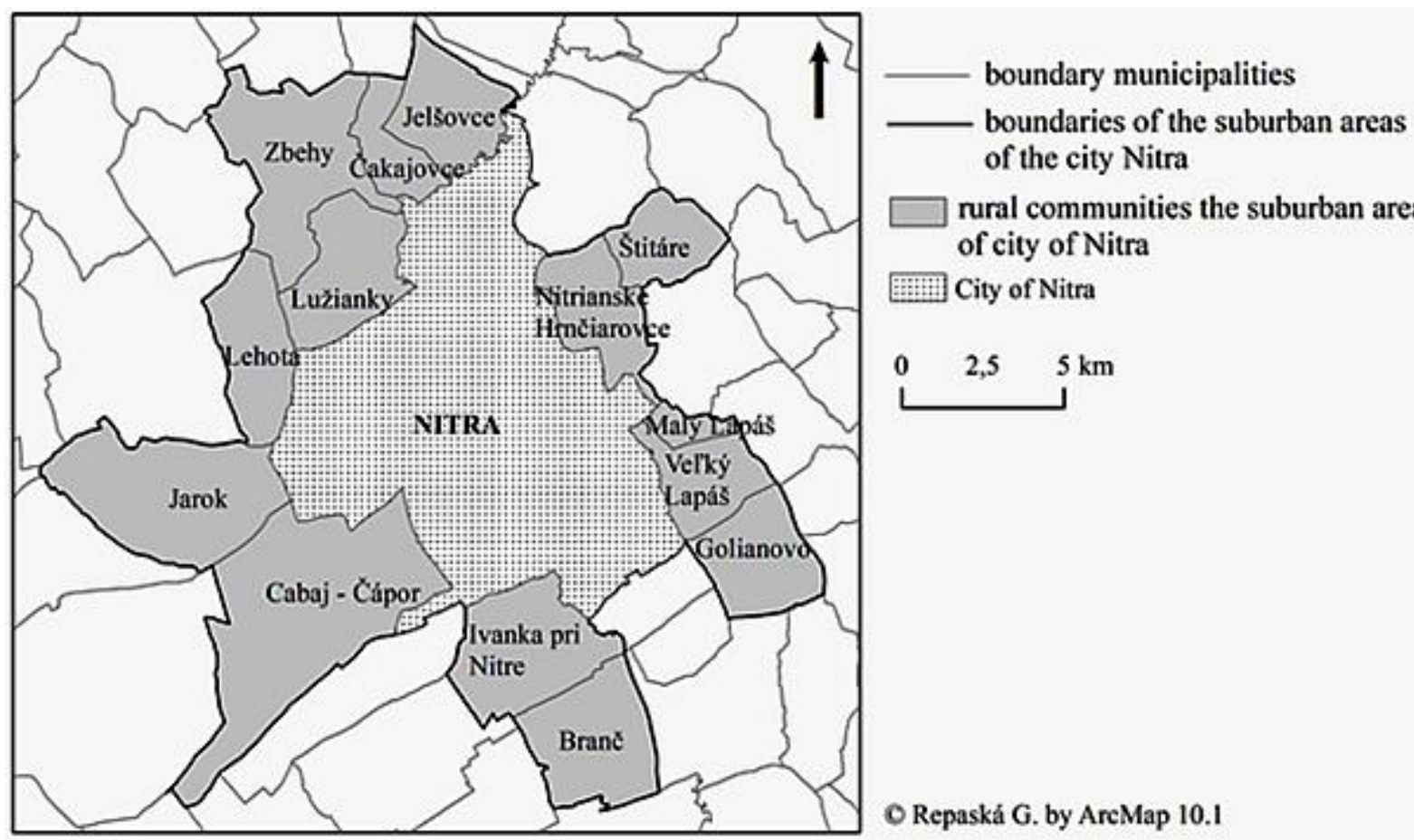
rural communities the suburban area of city of Nitra

City of Nitra

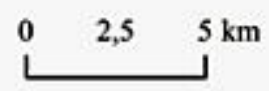

O Repaská G. by AreMap 10.1

Fig 1. Suburban zone of the city of Nitra (1998-2015).

Statistical data on the migration of the population in Slovakia have been made publicly available at the level of towns and rural municipalities through the statistical office since 1991; data on immigration, emigration and net migration is available. Population growth in rural areas and population decline in cities as well as rural positive net migration and urban negative net migration are important indicators for determining the future course of suburbanization. Figures indicating a rise in the number of immigrants to rural communities do not identify where the migrants come from. Similarly, positive net migration in rural communities does not identify immigrants from the city. It is therefore important to follow the direction of migrants, referring only to the migration of population from the city to the countryside. What is interesting is the proportion of immigrants from the city compared to the total number of immigrants; this has a significant dependence on the distance from the core city. Based on the direction of migration flows from the city to the countryside Repaská (2012) identified suburban zones of individual cities in the Nitra Region, while the rural municipalities of the suburban area of Nitra had been identified until 2009. In its allocation (in addition to the above indicators) a new key indicator was the portion of immigrants from the city of Nitra in each municipality of the total number of immigrants in the settlement; the condition was that the proportion of immigrants from the city of Nitra must be higher than the proportion of immigrants from other directions. For the needs of this paper, based on this methodology, the suburban area of Nitra was updated and defined until 2015. At present it consists of 14 rural municipalities (Fig. 1).

The essence of suburbanization is, in addition to the influx of new residents, the construction of new individual houses or apartments. The Statistical Office of the Slovak Republic provides data on the number of residential units; this information can be utilized to study the growth of households and the housing stock in each year, documenting their development. Suburbanization was evaluated based on this principle in foreign literature by Borén, Gentile (2007), Brown, Schafft (2002) and others. These data sources can be used not only for mapping suburban construction but also for assessing the concentration or dispersion of new settlement buildings.

A helpful source of information for mapping large residential suburban areas are aerial and satellite images (Bański, 2005, Sýkora, Ouředníček, 2007). Despite the fact that these resources for mapping large areas are quite difficult to process, their importance is essential, as they emphasized the importance of suburban development. In this paper, in order to derive a better comparison and more detailed localization and visualization of housing stock, aerial photographs from 2001 and 2015 were used. The method of field research was implemented to study 
the morphology of new suburban construction, and photographs of the actual construction of housing stock in rural villages were obtained.

\section{Residential development in rural communities of the suburban area of Nitra city - research results}

Various historical periods have brought changes to the urban environment and its outskirts, effected by human activity. The current state of the construction of houses and flats in Slovakia is the result of a complex historical development in an environment of different economic and political conditions. Residential suburbanization processes should be examined in the context of the specificities of the development of the functional spatial structure of a city that underwent the most remarkable changes in the period of socialism (Korec, Smatanová, 2000). Suburbanization trends in socialist Czechoslovakia were extremely limited. Within the cities in the 1950s, under political pressure, all rental houses were transferred to state ownership; there was a nationalization of factories and collectivization of agricultural land that was designated especially for agricultural use (Lauko, 2001, Slavík et al., 2011). Housing development was limited not only by lack of available land but also a lack of funds and building materials to build houses. During this period there were no social incentives for suburbanization, such as the separation of wealthier people from the poor and the need to live among neighbours of the same income and social class (Brandão et al., 2014). Weekend escapes from the city to cottages became a specific element of the lifestyle. The main function of the cottages was not dwelling, but recreation. The largest growth of such activities was recorded in the natural environment, where urban inhabitants developed a popular tradition of summerhouses. Weekend and holiday activities of cottagers contributed to the social life of small rural communes (Ouředníček, 2005). During socialism in the big cities, whole zones of typical residential blocks were formed. In this period quantity over quality was preferred. The intensification of residential zones having begun, there was an excessively high density of buildings that was also accompanied by inferior architectural and urban design and lower technical quality of the residential buildings with heavily underfunded amenities (Hirt, 2005).

The situation after 1989 brought many new elements into the economy, politics and society. They significantly began to change the conditions for housing construction and state housing policy. An important step in development of residential home building was the reduction in the protection of agricultural land, restitution of the land to original owners, the creation and advancement of new construction companies, opening of real estate agencies and the activities of newly established property development corporations (Golubchikov, Phelps, 2011, Tammaru, 2001). In the first half of the 1990s, the first signs of residential suburbanization in Slovakia started to show, but they were indistinctive. Construction of houses in the outskirts of Nitra was predominantly individual on individual lots. Slow development of residential suburbanization was probably caused by little state support for housing construction, but also low supply of building land. Highstandard housing could only be afforded by the part of the population with the highest income. At this time mortgage loans had not yet been introduced and construction savings came to the fore only in the second half of the 1990s. Expansion of mortgages to buy a house or apartment did not have such a rapid progress as in the case of home construction savings products. This was due to high interest rates and the residents not wanting to get into debt for a long period of time, as well as not having confidence in the future development of interest rates. Affordability of housing for households with low and middle income was inadequate. Demand for high standard houses on large lots decreased, because the highest income bracket had already obtained superior homes in the first half of the 1990s. In the late 1990s and early 2000 s due to the onset of property development companies, suburban development gradually began and the population started to migrate to the countryside (Korec, Smatanová, 2000). This trend was also recorded in the outskirts of Nitra, in which, according to Repaská (2012), suburbanization began after 2000. Building development was concentrated in locations further away from the city. New projects were prepared for the construction of small houses. Some residents also received support from the government and with lower interest rates mortgages became more affordable. Large villages located in the outskirts of towns in this period were becoming attractive. A major role was once 
again played by large housing projects. Due to the lack of suitable land for individual construction, semi-detached houses or blocks structurally related to each other expanded.

The suburban zone of Nitra now covers 14 municipalities. Residential buildings are the most visible manifestation of a process of suburbanization and a necessary part. Its monitoring is essential for understanding the complex changes in the spatial organization of human activities that take place in the outskirts of cities. Villages have become the location for the construction of several new residential areas, which are subject to current trends (building houses on small lots, dense built-up areas, cul-de-sacs and private roads, etc.). For the period 2001-2015, the total increase in the housing stock in municipalities was 16\%; the highest increase was in the village of Malý Lapáš, which reached almost $50 \%$. A significant $25 \%$ increase was also in Štitáre and over a $15 \%$ increase in the number of housing units was observed in the villages of Golianovo, Lehota, Lužianky and Nitrianske Hrnčiarovce (Graph 1).

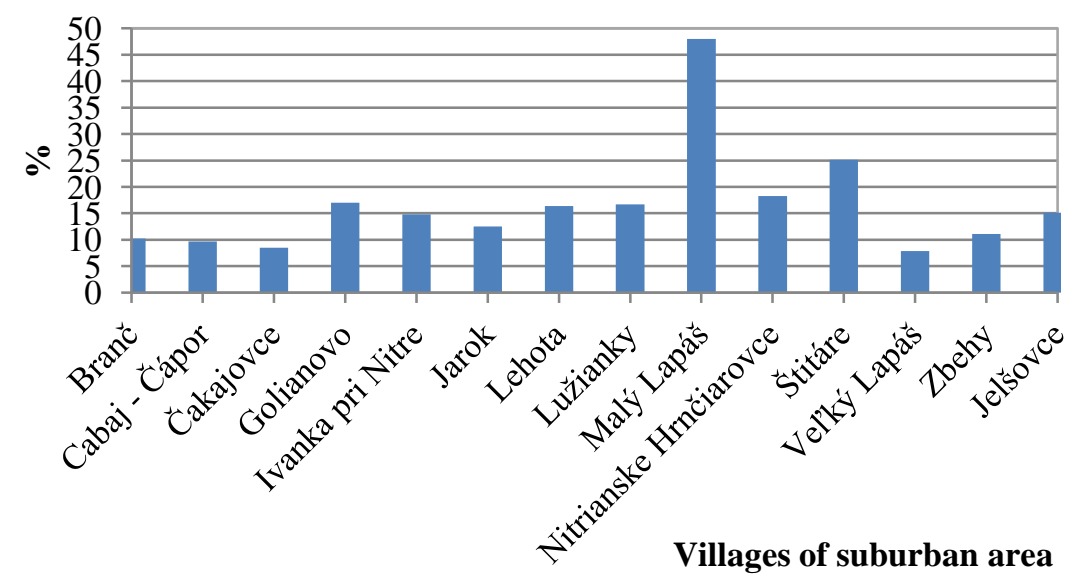

Increase of the number of houses from 2001 to 2015 in \%

Graph 1. Increase the number of houses in rural areas the suburban area of Nitra from 2001-2015. Source: Statistical Office of the Slovak Republic, 2015

The development of housing stock has experienced a significant evolution. In the 1960s requirements on quality and availability of housing increased dramatically, which translated into large-scale construction. But despite this fact, this period began with the construction of new types of houses. Long rectangular gable houses were stopped being built, and instead L-shaped houses prevailed. In the mid-1960s, a new type of building with a square base and a pyramidal roof began to be built, which is referred to as a square. At the end of the 1960s there were one-storey houses with flat and pyramidal roofs. According to Nekoranec (2015) in 1960 in Slovakia, more than 300,000 houses were built. In the period 1960 to 1990 houses with basement built-in garages began to be built. Family houses built after 1990 were characterized by the diversity of materials used. This was due to the increase in financial security of the residents, who were able to build their houses in a shape and size allowing customized solutions. Generally, this concerned the construction of energy-intensive and expensive houses. Many were sealed from the environment with opaque walls and often did not respect the character of the surrounding buildings (Nekoranec, 2015).

Rural communities in the suburban areas of Nitra are in terms of spatial distribution of suburban building broadly diversified, which we confirmed by field research. The most common form of new housing are individual family houses for which a customer procures construction, or hires a construction company that implements turnkey construction (Fig. 2). Another form of new construction is the mass construction of houses. It is implemented through developers. Developers buy land in rural areas, add the necessary infrastructure, parcel out building lots and sell them. Such types of houses are very convenient for companies because their construction in accordance with the land use plan, is not an issue and their connection to utility networks is technically and financially less demanding (Fig. 3). Communities are usually dominated by standalone (isolated) houses. Semi-detached and townhouses represent a smaller number. 


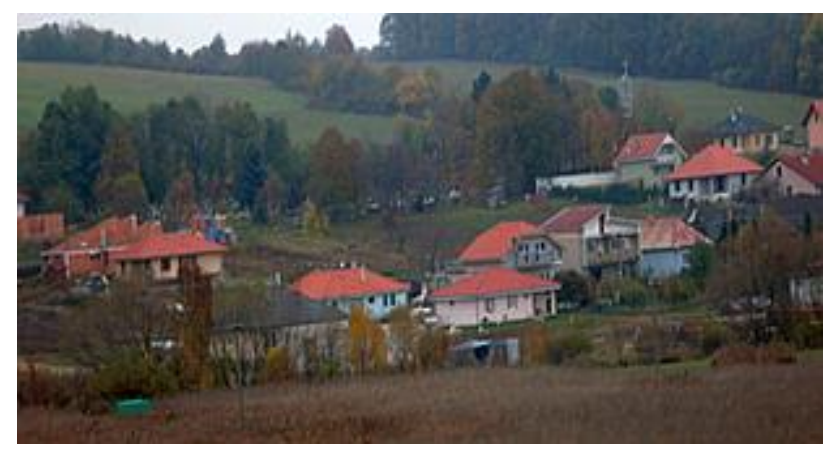

Fig 2. Individual construction of Malý Lapáš

Photos: Repaská, Vilinová, Šolcová, 2015

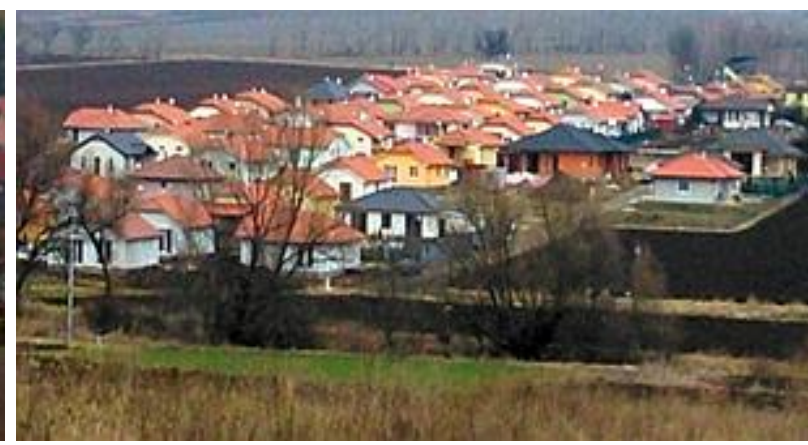

Fig 3. Mass construction of houses in the village of Golianovo

Detached houses provide the highest intimacy of housing and family life, ensuring direct contact with a garden and nature. The advantage of this housing is versatility in orientation to the cardinal points, and maximum sunlight, ventilation and hygiene. The disadvantage is the difficulty of the size of the land associated with the higher cost of investment due to the fact that the isolated house is exposed to weather conditions. Detached houses can be divided into small, medium, large, villas and residences (STN 73 4301). In the suburban villages of Nitra, all of these types of houses are represented, excluding residences. The useful area of a small house is typically within $150 \mathrm{~m}^{2}$, a medium-sized house of $150-200 \mathrm{~m}^{2}$ and a large house of $200 \mathrm{~m}^{2}$ (Fig. 4-6). Villas (Fig. 7) symbolize great prestige and solid social status. The ownership of a villa manifests an above-average standard of living. A villa usually has 3-4 bedrooms, obviously all spacious, light-filled and each quite satisfactory for living (Blažková, 2006). Fencing or high walls with CCTV and other security devices indicate a desire for isolation by owners. In the municipalities of the suburban areas of Nitra mainly three-room and four-room bungalows with land price ranges from $35 € / \mathrm{m}^{2}$ to $100 € / \mathrm{m}^{2}$ (Nitrianske Hrnčiarovce) dominate and their size is from 4 to 10 acres (Table 1).

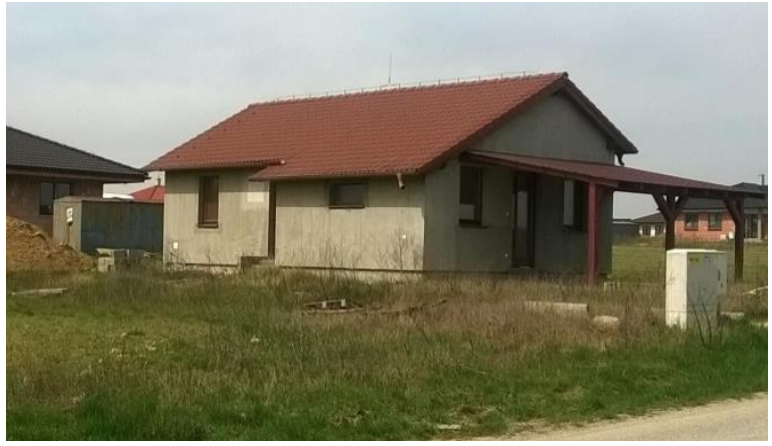

Fig 4. Small detached house in the village of Velký Lapáš

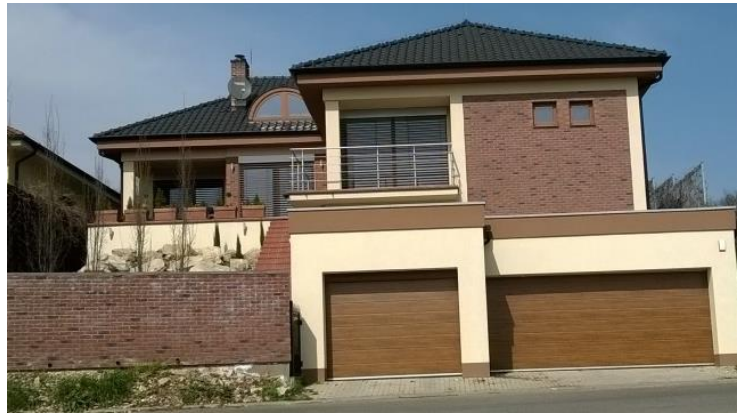

Fig 6. Large detached house in the village Nitrianske Hrnčiarovce

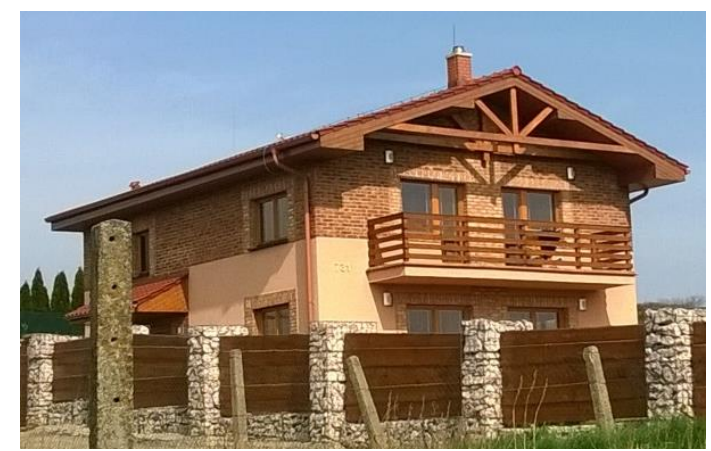

Fig 5. Medium detached house in the village of Lehota

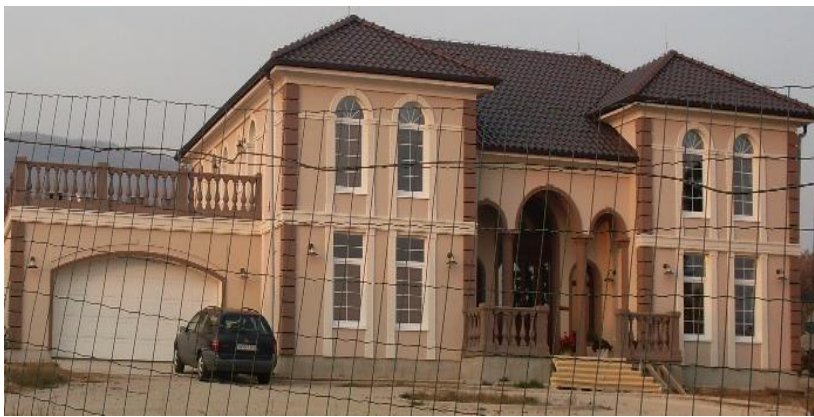

Fig 7. Villa in the village of Nitrianske Hrnčiarovce

Photos: Repaská, Vilinová, Šolcová, 2015 
The duplex family house (Fig. 8) is more sensitive to the orientation to the cardinal points, but allows, for example, multigenerational housing (Smola, 2007). Duplex houses share a common wall; the perimeter of each house is independent of the remaining three sides. Regarding contact with the garden, the advantages are the same as for a detached house. A duplex family house is very convenient as it is cheaper because of the cost of land, utility connections and fenced land. The disadvantage of a duplex house is that half of the house tends to have inferior orientation to the cardinal point. The layout of a duplex house is normally selected so that the greatest possible portion of the lot stays well illuminated by sunlight, based on the location within the lot (closer or farther away from the street). This also reduces the communication area. The entrances are designed to be located from the side of the street or from the sides of the house (Blažková, 2006). In the villages of the suburban zone duplex family houses occur in the village of Branč, where 12 duplex houses have been built and occupied (Table 1, Fig. 9).
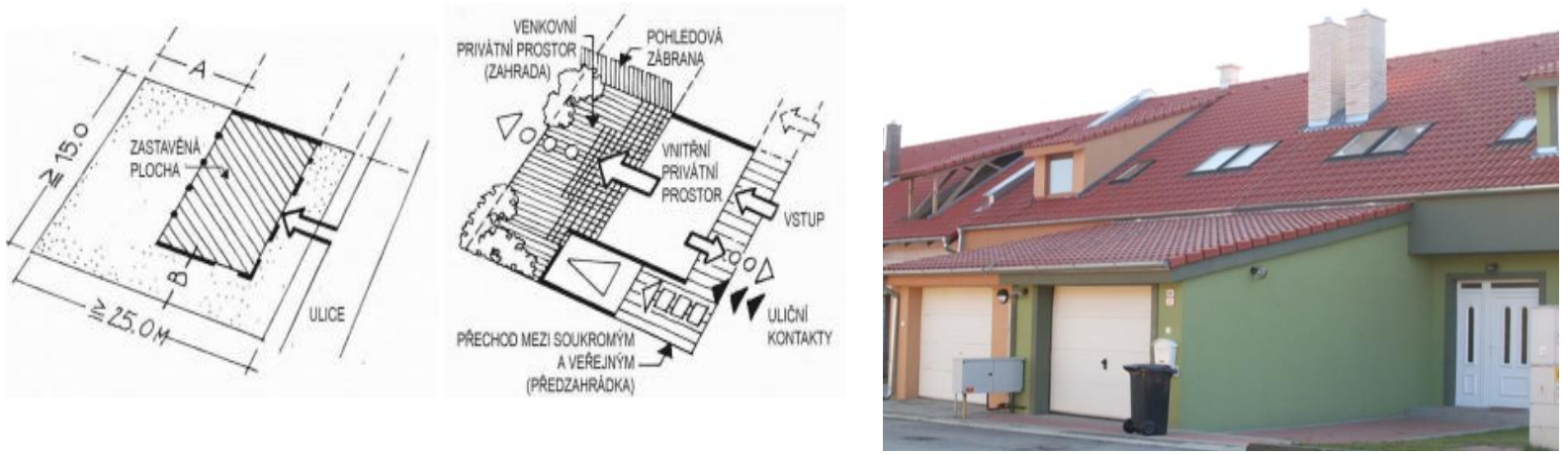

Fig 8. Ground plan of duplex family house. Source: Blažková, 2006

Fig 9. Duplex family house in the of village Branč. Photo: Repaská, Vilinová, Šolcová, 2015

Row houses in suburban villages are represented only in the village Nitrianske Hrnčiarovce, where there is one street with 35 houses of this type (Fig. 10,11). From the perspective of their floor space, row houses are among the most efficient types of family houses. While a duplex house has only one common wall that reduces the loss of heat in winter months, row houses have two mutually protected walls on both sides. Most often these are multi-storey buildings with an identical layout, built linearly next to each other or tied together so side walls of individual houses overlap only partially. To better distinguish individual houses, the facade of each housing unit may be painted in a different color. Since the private lot behind the house is separated from the public by the building itself, row houses do not usually have traditional fencing or a front garden. The space in front of the house most often has a simple lawn, a few shrubs or a hedge fence. Part of this area consists of a parking space or garage entrance. Living in a row house approaches the quality of inhabitation of a detached home, but their appearance resembles apartment buildings. The streets in front of row houses are usually open to public and accessible by anybody, which along with the lack of fencing may induce a feeling of greater vulnerability or lack of privacy (Smola, 2007).

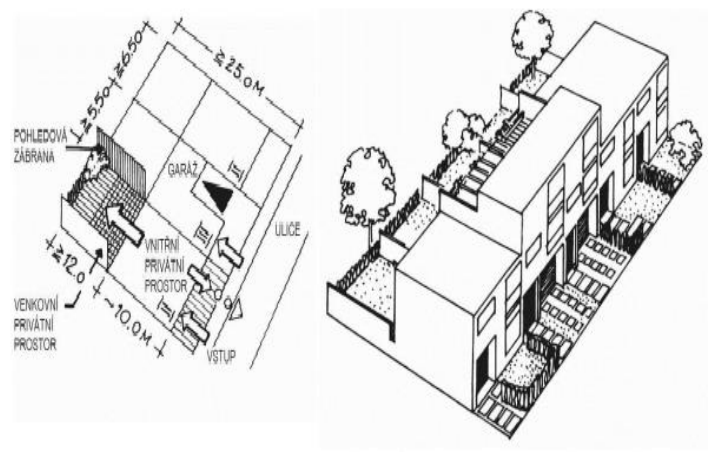

Fig 10. Ground plan of townhouse. Source: Blažková, 2006

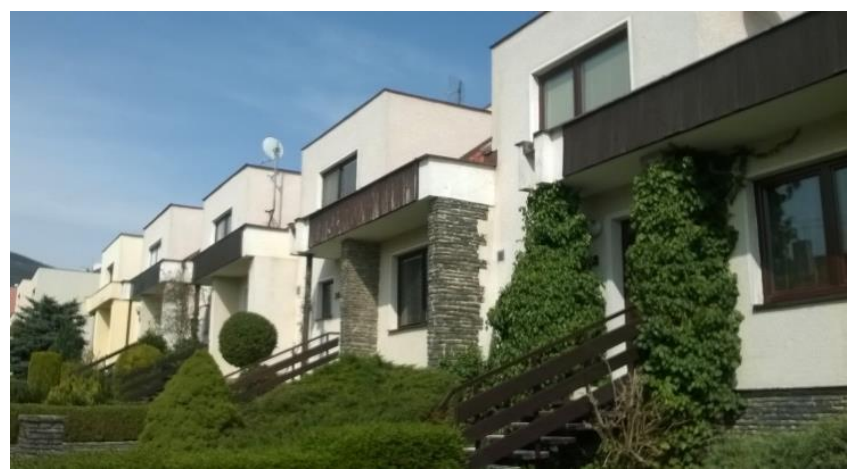

Fig 11. Townhouses in the village Nitr. Hrnčiarovce. Photos: Repaská, Vilinová, Šolcová, 2015 
In terms of suburbanization apartment blocks for residents migrating from the city are also interesting. In the suburban zone apartment buildings occur in the village Golianovo (1) Jarok (2) and Vel'ký Lapáš (3) (Table 1).

Tab 1. Number of houses in the residential construction in suburban villages of Nitra.

\begin{tabular}{|l|r|r|r|r|r|}
\hline \multirow{2}{*}{$\begin{array}{c}\text { Municipalities of the Nitra } \\
\text { suburban area Nitra }\end{array}$} & $\begin{array}{c}\text { The number of houses in } \\
\text { the area of new } \\
\text { construction }\end{array}$ & \multicolumn{2}{c|}{$\begin{array}{c}\text { The number of } \\
\text { residential buildings }\end{array}$} & $\begin{array}{c}\text { Land price } \\
\text { per } 1 \mathrm{~m}^{2}(€)\end{array}$ \\
\cline { 2 - 6 } & overall which & $\begin{array}{c}\text { of } \\
\text { inhabited }\end{array}$ & overall & $\begin{array}{c}\text { of which } \\
\text { inhabited }\end{array}$ & \\
\hline Branč & 111 & 90 & 0 & 0 & 33 \\
\hline Cabaj Čápor/Nový Cabaj & $68 / 104$ & $35 / 94$ & 0 & 0 & $35 / 59$ \\
\hline Golianovo & 72 & 65 & 1 & 1 & 35 \\
\hline Jarok & 42 & 30 & 2 & 2 & 35 \\
\hline Jelšovce & 38 & 25 & 0 & 0 & 35 \\
\hline Lehota & 53 & 5 & 0 & 0 & $50-66$ \\
\hline Lužianky & 75 & 62 & 0 & 0 & 35 \\
\hline Malý Lapáš & 275 & 150 & 0 & 0 & 35 \\
\hline Nitrianske Hrnčiarovce & 107 & 90 & 0 & 0 & 100 \\
\hline Zbehy & 33 & 22 & 0 & 0 & 35 \\
\hline Štitáre & 55 & 38 & 0 & 0 & 50 \\
\hline Ivanka pri Nitre, & 68 & 40 & 0 & 0 & 50 \\
\hline Čakajovce & 123 & 18 & 0 & 0 & 35 \\
\hline Vel'ký Lapáš & & 20 & 3 & 2 & 35 \\
\hline
\end{tabular}

Source: Field research, 2015

The spatial location of suburban construction in selected villages in the outskirts of Nitra shows significant changes when aerial photographs from 2001 and 2015 are compared. Houses are built in two ways. The first way has new residential areas added to the existing settlement structure of municipalities, such as the construction of suburban additional residential development. Construction of family houses in that situation can be perceived positively, as the experience of Western Europe and North America has shown that the creation of solitary suburban settlements brings excessive demands on energy consumption and has a far-reaching impact on the development of suburban areas (Nuissl \& Rink, 2005). An advanced construction method is the compact residential development (Fig. 12), which is characterized by a regulated construction project of a whole complex of family turnkey houses in a pre-allocated area managed by a broker or property developers. The independent suburban communities established are significant architecturally and socially separated from the original rural communities. 


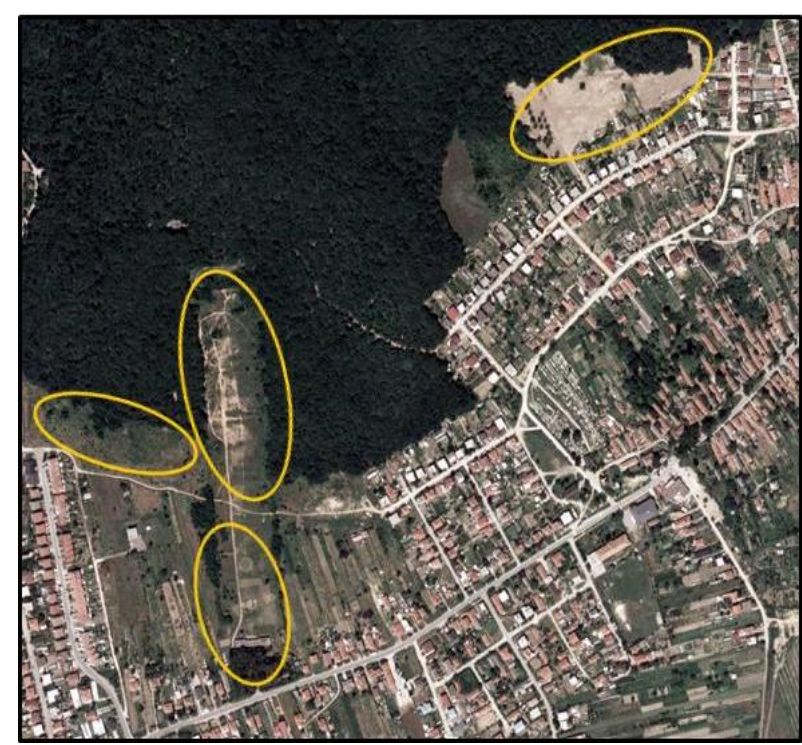

Nitrianske Hrnčiarovce 2001

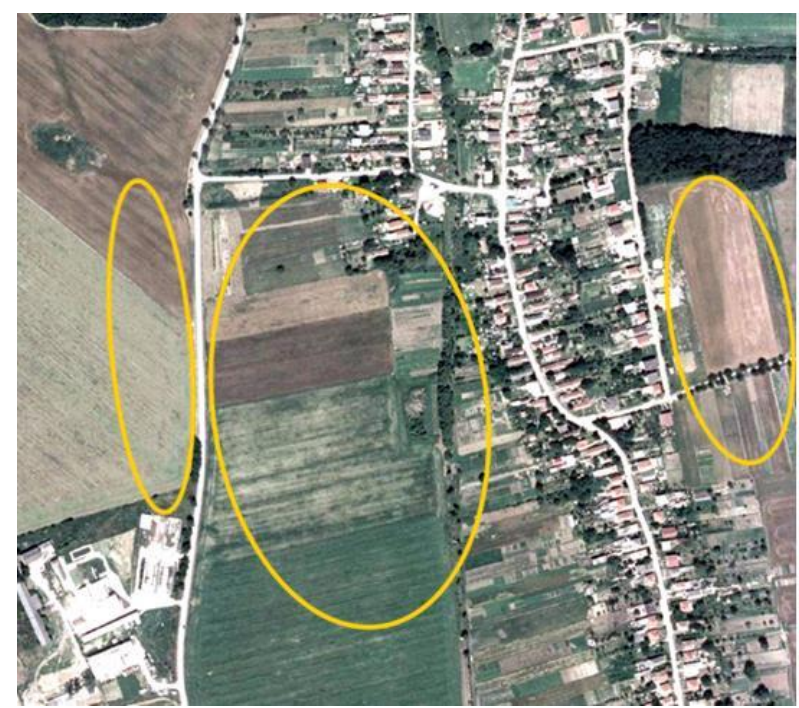

Malý Lapáš 2001

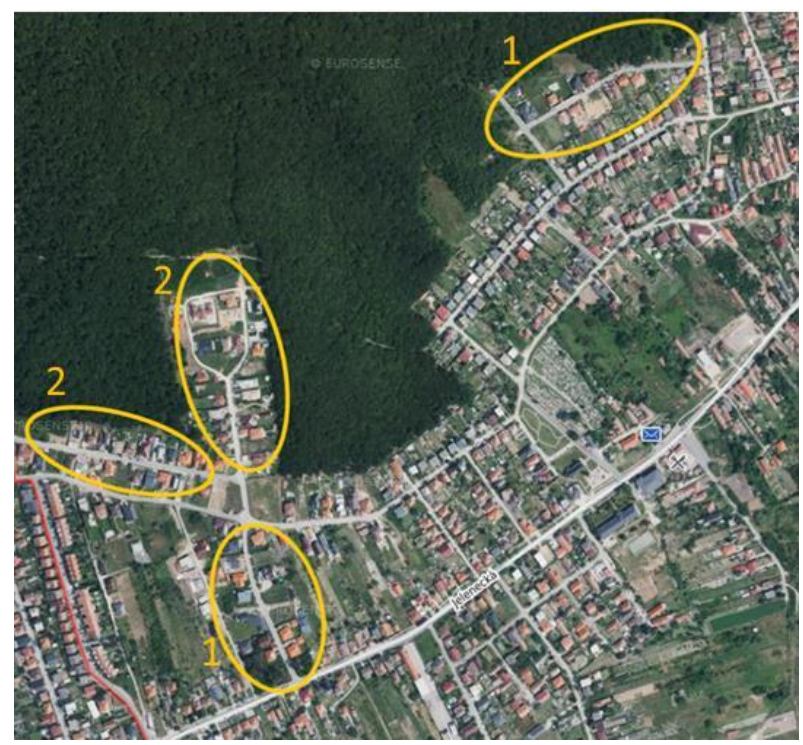

Nitrianske Hrnčiarovce 2015

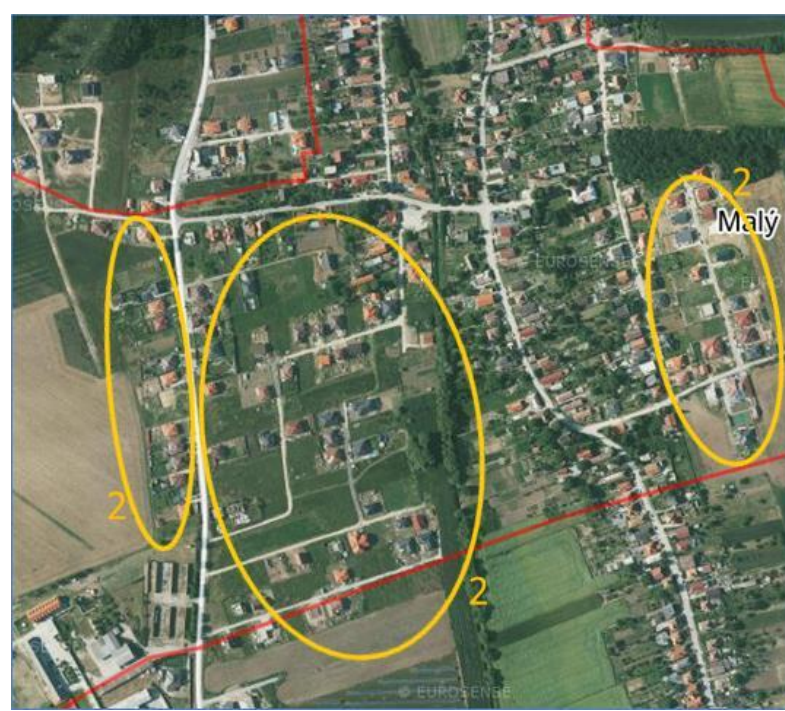

Malý Lapáš 2015

Fig 12. Additional and compact residential development in the example of the municipalities Nitrianske Hrnčiarovce and Malý Lapáš (comparison 2001 and 2015). 1 - additional building, 2 - compact construction Source: Aerial photos $(2001,2015)$

\section{Conclusion}

While studying the relevant literature on suburbanization from various post-socialist countries, it is clear that there is no single view on suburbanization or stable definition. Different opinions are mainly associated with a different intensity and spatial expression which influence this process in different geographic, cultural and economic conditions. Big cities and their processes can be seen in post-socialist Europe as places of first entry of new economic and cultural elements into regions (Borén, Gentile, 2007, Leetmaa et al., 2012, Ouředníček, Špačková, 2013), but also as a connection between Western and Eastern Europe (Musil, 2005) and as outposts for spreading new development tendencies and trends into other areas. Suburbanization in post-socialist countries is influenced by specific historical, legal and political conditions that do not allow a straightforward comparison of suburbanization with analogous processes in Western Europe. It should be stressed that in Western Europe suburbanization took place in an environment of strong population and economic growth, while in post-socialist countries, we are rather witnessing population stagnation and economic transformation (Nuissl, Rink, 2005). We agree with Ouředníček (2007), Sýkora (2003), Otto (2001) that for monitoring the size and geographic scope 
of residential suburbanization, methods of monitoring population growth of suburban municipalities and their housing construction should be used. In the case of residential suburbanization, it is clear that there is a gradual hierarchical spreading of housing construction in Slovakia and likewise in the Czech Republic (Ouředníček, 2007), Hungary (Timár, Váradi, 2001) and in Poland (Zębik, 2011). In the early 1990s, it was the first time we could notice significant changes in the migratory behaviour of the population of Slovak cities - Bratislava and Košice. This trend has gradually gained intensity and has begun to be manifested also in other major cities in Slovakia. Slow urban growth was in the second half of the 1990s substituted by gradual population decline, and population growth was recorded in neighbouring suburban areas (Matlovič, Sedláková, 2007). Historical development and the current state of Slovak towns and their surroundings affect the potential for further residential development. The change of social and economic conditions after 1989 created the preconditions for starting the process of suburbanization which are manifested mainly through large-scale housing construction. In the Slovak literature this process is evaluated in the examples of cities such as Bratislava (Slavík et al., 2011), Košice (Novotný, 2014), Prešov (Matlovič, Sedláková, 2007), and Nitra (Repaská, 2012). Medium-sized towns in Slovakia were evaluated by Repaská (2012) only at the level of the Nitra Self-governing Region. Definition of the suburban zone of the city of Nitra on the basis of data synthesis depends also on the city itself. The potential for suburbanization is regularly distributed around the city, as suburban municipalities are close to the city and share administrative boundaries. This fact affects residential suburbanization which is related to migration of population and housing construction of individual municipalities. Analysis of changes referred to the differentiated extent and increase in built-up areas in the suburban zone of Nitra, leading to the expansion of residential construction in the studied area. On this basis, the rural municipalities are under constant pressure and constant change, but also development. Trends in the development of residential construction should be based on the requirements to integrate the advantages of urban and rural housing. These trends are associated with the use of new effective forms of residential development and construction of diverse types of buildings. In studying the manifestations of residential suburbanization in the outskirts of Nitra, it is evident that new construction shall enter into various forms with different requirements for spatial arrangement. New residential locations are linked to the residential buildings already existing, or establish new neighborhoods of houses without following the original urban area of the village. These require quite large and undeveloped areas (i.e. construction on "greenfield"), therefore almost exclusively, are carried out on the edges of existing settlements, but often in isolation from the original village. This creates completely new suburban settlements, which are characterized by highly built-up area density, small lots of land and an inadequately connected street system with many dead-end streets. Such an example can be seen with the increase of compact built-up areas in the village of Malý Lapáš, where there was an increase in the housing stock from 2001 to 2015 of almost 50\%. Several Czech and Slovak cities grew in a similar way (Slavík et al., 2007, Sýkora, Ouředníček, 2007).

Academic references

[1] Bański, J. (2005). Suburban and Peripheral Rural Areas in Poland: The Balance of Development in the Transformation Period. Geografický časopis 57(2), 117-129.

[2] Blažková, M. (2006). Bydlení. In: Principy a pravidla územního plánování (pp. 2-52). Brno: Ústav územního rozvoje.

[3] Borén, T. \& Gentile, M. (2007). Metropolitan Processes in Post-communist States: an Introduction. Geografiska Annaler: Series B, Human Geography. 89(2), 95-110. DOI: 10.1111/j.1468-0467.2007.00242.x.

[4] Brandão, V. A. B., Riveira, I. S., Maseda, R. C. \& Neto, J. A. F. (2014). Social Analysis of the Factors that Influence the Development and Planning of Rural Settlements: The Cases 
of the Municipalities of Cervantes and Guitiriz in Galiza. Dados. 57(3), 711-744. DOI: 10.1590/00115258201422.

[5] Brown, D. L. \& Schafft, K. A. (2002). Population Deconcentration in Hungary during the Postsocialist Transformation. Journal of Rural Studies. 18 (3), 233-244. DOI: 10.1016/S07430167(01)00046-8.

[6] Cílek, V. \& Baše, M. (2005). Suburbanisation of the Prague Surrounding: Impacts on Social Environment and Landscape. [online]. Available at: http://www.vizezasova.cz/images/suburbanizace_1.pdf. [Accessed 5 September 2016].

[7] Glenn, N. D. (1973). Suburbanisation in the United States since World War II (pp. 51-78). In: The Urbanisation of the Suburbs. Beverly Hills, CA: Sage Publication.

[8] Golubchikov, O. \& Phelps, N. A. (2011). The Political Economy of Place at the Post-socialist Urban Periphery: Governing Growth on the Edge of Moscow. Transactions of the institute of British Geographers. 36(3), 425-440. DOI: 10.1111/j.1475-5661.2011.00427.x.

[9] Hirt, S. (2005). Planning the Post-communist City: Experiences from Sofia. International Planning Studies. 10(3-4), 219-240. DOI: 10.1080/13563470500378572.

[10] Kährik, A. \& Tammaru, T. (2008). Population Composition in New Suburban Settlements of the Tallinn Metropolitan Area. Urban Studies. 45(5-6), 1055-1078, DOI: $10.1177 / 0042098008089853$.

[11] Korec, P. \& Smatanová, E. (2000). Development of Distribution of the Flat Pool in the Territory of Bratislava, the Laws and Specific Features of the Process. Geografický časopis 52(1), 51-66.

[12] Kramer, J. (1972). North American Suburbs: Politics, Diversity, and Change. Berkeley: The Glendessary Press.

[13] Lauko, V. (2001). Mestské sídla Slovenska a ich trvaloudržatel'ný rozvoj (pp. 59-79). In: Geografické štúdie No. 8. Banská Bystrica: Matej Bel University.

[14] Leetmaa, K., Brade, I. Anniste, K. \& Nuga, M. (2012). Socialist Summer-home Settlements in Post-socialist Suburbanisation. Urban Studies 49(1), 3-21. DOI: $10.1177 / 0042098010397399$.

[15] Lupi, T. \& Musterd, S. (2006). The Suburban Community Question. Urban Studies 43(4), 801-817. DOI: 10.1080/00420980600597723.

[16] Matlovič, R. \& Sedláková, A. (2007). The Impact of Suburbanisation in the Hinterland of Prešov (Slovakia). Moravian Geographical Reports 15(2), 22-31.

[17] Mayer, V. (2000). Teoretické a metodologické úvahy k problematike suburbanizace bydlení ve Vídeňské aglomeraci. Urbanizmus a územní rozvoj. 6(6), 7-14.

[18] Mumford, L. (1961). The City in History. Harmondsworth: Penguin.

[19] Musil, J. (2005). Prague Returns to Europe (pp. 281-317). In: Transformation of Cities in Central and Eastern Europe: Towards, Globalization. Tokyo: United Nations University Press.

[20] Nekoranec, P. (2015). Rodinné a bytové domy - znižovanie energetickej náročnosti: obnova. Pezinok: Dynamics SK.

[21] Novotný, L. (2014). The Processes of Spatial Redistribution of Population and their Impact on the Changes in the Population Structure in the Košice Functional Urban Region. Košice: Pavol Jozef Šafárik University.

[22] Nuissl, N. \& Rink, D. (2005). The 'Production' of Urban Sprawl in East Germany as a Phenomenon of Post-socialist Transformation. Cities 22(2), 123-134, DOI: 10.1016/j.cities.2005.01.002. 
[23] Ott, T. (2001). From Concentration to De-concentration - Migration Patterns in the Postsocialist City. Cities. 18(6), 403-412. DOI: 10.1016/S0264-2751(01)00032-4.

[24] Ouředníček, M. (2005). New Suburban Development in the Post-socialist City: the Case of Prague (pp. 143-156). In: Paths of Urban Transformation. Frankfurt am Main: Peter Lang.

[25] Ouředníček, M. (2007). Differential suburban development in the Prague urban region. Geografiska Annaler: Series B, Human Geography. 89(2), 111-126, DOI: 10.1111/j.14680467.2007.00243.x.

[26] Ouředníček, M. \& Špačková, P. (2013). Teoretické přistupy a současná témata výzkumu suburbanizace (pp. 13-36). In: Sub Urbs: Krajina, sídla, lidé. Praha: Academia.

[27] Putnam, R. D. (2000). Bowling Alone: the Collapse and Revival of American Community. New York: Simon\&Schuster.

[28] Repaská, G. (2012). Residential Suburbanization of Towns and Cities of the Nitra Selfgoverning Region (Empirical Example of the Nitra City). Nitra: Constantine the Philosopher University.

[29] Repaská, G., Vilinová, K. Dubcová, A. \& Kramáreková, H. (2015). Residential identity as a phenomenon in the context of suburbanization (case study of suburbs of the city of Nitra). Geografický časopis. 67(2), 107-126.

[30] Sjöberg, Ö. \& Tammaru, T. (1999). Transitional Statistics: Internal Migration and Urban Growth in Post-Soviet Estonia. Europe-Asie Studies 51(1), 821-842.

[31] Slavík, V., Grác, R., Klobučník, M. \& Kohútová, K. (2011). Development of Suburbanizations of Slovakia on the Example of the Bratislava region (pp. 35-38). In: Urban Regions as Engines of Development. Warsaw: Polish Academy of Science, Commitee for Spatial Economy and Regional Planning.

[32] Smola, J. (2007). Stavba rodinného domu krok za krokem. Praha: Grada Publishing.

[33] Soós, G. \& Ignitz, G. (2003). Suburbanisation and its consequences in the Budapest metropolitan area. Weimar: Bauhaus-Universität.

[34] Sýkora, L. (2003). Suburbanizace a její společenské důsledky. Sociologický časopis 39(2), 217-232.

[35] Sýkora, L. \& Ouředníček, M. (2007). Sprawling Post-communist Metropolis: Commercial and Residential Suburbanisation in Prague and Brno, the Czech Republic (pp. 209-233). In: Employment Deconcrentration in European Metropolitan Areas: Market Forces Versus Planning regulations. Dordrecht: Springer.

[36] Tammaru, T. (2001). Suburban growth and suburbanisation under central planning: The case of Soviet Estonia. Urban Studies. 38(8), 1341-1357. DOI: 10.1080/00420980120061061.

[37] Tammaru, T., Leetmaa, K., Silm, S. \& Ahas, R. (2009). Temporal and spatial dynamics of the new residential areas around Tallinn. European Planning Studies. 17 (3), 423-439, DOI: $10.1080 / 09654310802618077$.

[38] Timár, J. \& Váradi, M. M. (2001). The Uneven Development of Suburbanisation During Transition in Hungary. European Urban and Regional Studies. 8(4), 349-360. DOI: $10.1177 / 096977640100800407$.

[39] Wecławowicz, G. (1998). Social Polarisation in Postsocialist Cities: Budapest, Prague and Warsaw (pp. 55-66). In: Social Change and Urban Restructuring in Central Europe. Budapest: Akadémiai kiadó.

[40] Zębik, G. (2011). Typology of suburban communities in Poland. In: Bulletin of Geography. Socioeconomic Series 16, 173-188. DOI: 10.2478/v10089-011-0021-x. 
[41] Statistical Office of the Slovak Republic. [online]. Available at: www.statistics.sk [Accessed 19. 5. 2016].

[42] STN 734301 Budovy na bývanie [Dwelling buildings]. Bratislava: Slovenský ústav technickej normalizácie, 2005. 